\title{
Energy balance, gonad development and biochemical composition in the clam Ruditapes decussatus
}

\author{
A. Pérez Camacho, ${ }^{1, *}$, M. Delgado ${ }^{1}$, M. J. Fernández-Reiriz ${ }^{2}$, U. Labarta ${ }^{2}$ \\ ${ }^{1}$ Instituto Español de Oceanografía, Muelle de Ánimas s/n, 15001 La Coruña, Spain \\ ${ }^{2}$ Consejo Superior Investigaciones Cientificas (CSIC), Instituto de Investigaciones Marinas, Eduardo Cabello 6, \\ 36208 Vigo, Spain
}

\begin{abstract}
This study evaluates the influence of different states of energy balance, positive and negative, on the accumulation and utilisation of energy reserves during the period of gonad development in the clam Ruditapes decussatus (L.). Our results show a clear sexual differentiation in the biochemical composition of the clams. The differences were associated with gonad development and were particularly evident in proteins and lipids. These findings imply that separation of the sexes for studying variations in the biochemical composition of sexually developed specimens is essential, and thus questions the results of previous studies in which both sexes were analysed simultaneously. Gonad development occurs under conditions of both positive and negative energy balance, and permits the development of a model of the utilisation of reserves during gonad development, which is closely linked to the clam's energy balance. Under conditions of positive energy balance, the amount of food ingested provides sufficient energy for both metabolic consumption and the accumulation of reserves. The absolute value of all biochemical components increases, in particular for lipids in the case of female clams, with no evidence of consumption of glycogen and other carbohydrates or their conversion into lipid reserves. Conditions of negative energy balance lead to a moderate degree of organic weight loss in the clams. Glycogen and other carbohydrates are rapidly consumed, falling to almost a quarter of initial values, whilst protein and lipid levels remain constant in females. Lipid values decrease slightly in males. Finally, under situations of extreme nutritive stress (when energy reserves are scarce) there is a loss of all biochemical components in a specific order of priority. Most of the glycogen and other carbohydrates are consumed initially (a decrease of 61 and $74 \%$, respectively), followed to a lesser extent by lipids in males (40\%) and then proteins (between 20 and $25 \%$ ). In females, there was no lipid loss until the majority of the carbohydrates and part of the proteins had been consumed, indicating that lipids constitute the reproductive reserve par excellence in this species.
\end{abstract}

KEY WORDS: Ruditapes decussatus · Energy balance · Gonad development · Biochemical composition Resale or republication not permitted without written consent of the publisher

\section{INTRODUCTION}

Food availability and temperature are the main factors affecting both growth and reproduction of bivalves. The effect of these variables is complex and depends specifically on acquisition and expenditure of energy in the natural environment (Bayne \& Newell 1983). Surplus energy is allocated to somatic growth and gonad development.
Goodman (1979) studied reproductive strategies as a function of reproductive cost and survival probabilities as a function of age. Similarly for Ruditapes decussatus in North Spain, Urrutia et al. (1999) established that its reproductive strategy (delay of sexual maturation and low reproductive effort) is associated with nutritional constraints arising from prolonged periods of emersion and a virtual lack of metabolic compensation for variability in factors such as temperature. The reproduc- 
tive strategy of this species seems to be associated with food availability. Food availability is not exclusively associated with differences in the various distribution areas of a species; it includes inter-annual variability in food supplies that requires adaptative strategies. The accumulation of reserves, the allocation of stored energy to somatic growth or to the germinal pathway, and the importance of each gross biochemical component to the reproductive process under different nutritional conditions all play a role in the adaptative strategies to different habitats or areas of a given species (Goodman 1979).

Seasonal changes in the biochemical composition of bivalve molluscs have been widely studied in species in their natural habitat (Ansell 1972, 1974a,b, Walne \& Mann 1975, Newell \& Bayne 1980, Zandee et al. 1980, Robert et al. 1993). In general, changes in each biochemical component are closely linked to the state of sexual maturity of the mollusc, and are related to energy supply either directly from the ingested food or from previously stored reserves (Sastry 1979, Navarro et al. 1989). Based on the relationship between gonad development and the accumulation and utilisation of nutrients, species can be classified as either conservative or opportunist (Bayne 1976). In the former category, gametogenesis takes place at the expense of previously acquired reserves (Zandee et al. 1980, Bayne et al. 1982). In the latter, gametogenesis occurs when there is an abundance of food in the environment, and sexual maturing parallels the accumulation of nutrients.

In adult marine bivalves, carbohydrates, particularly glycogen, are considered to be the main energy source. Carbohydrates are important for forming gametes and maintaining adult condition during periods of nutritive stress or in winter (de Zwaan \& Zandee 1972, Gabbott 1975). Variations in carbohydrate content show an inverse relationship with the state of gonad maturity (Beninger 1982, Martínez et al. 1993). According to Beninger \& Lucas (1984), lipids form part of the reserves during periods of nutritional deficiency and are an important component of bivalve oocytes (Holland 1978), hence their maximum levels occur in the pre-spawning period (Taylor \& Venn 1979). Finally, proteins constitute, quantitatively, the largest fraction in the oocytes and other soft tissues of bivalves, and assume the role of energy providers during sexual maturation (Holland 1978).

Most of the information currently available proceeds from studies carried out in the natural medium. Under such conditions, food availability varies during the period of sexual maturation, concomitant with other environmental conditions, and it is therefore difficult to establish a direct relationship between a given state of energy balance (positive, negative, or zero) and the sexual maturation process or the utilisation of energy reserves. Therefore, the aim of the present study was to determine, under controlled laboratory conditions, the influence exerted by different states of energy balance on the accumulation and utilisation of reserves throughout sexual maturation. A further aim, given the foreseeable difference in behaviour between females and males, was to determine possible differential responses to changes in the various biochemical components as a function of sex.

\section{MATERIALS AND METHODS}

Breeding stock. The experiments were performed over 2 yr, using adult specimens Ruditapes decussatus collected from the Ría de Arosa (NW Spain). For the first set of experiments (Diets A, B and C), the initial average length of the clams was $20.8 \pm 0.15 \mathrm{~mm}$, with an average live weight of $1.60 \pm 0.31 \mathrm{~g}$. For the second set of experiments (Diets D and E), initial average length was $36.0 \pm 0.19 \mathrm{~mm}$ and average live weight $9.97 \pm 1.53 \mathrm{~g}$.

Experimental conditions. The experiments were performed in 121 plastic tanks containing natural seawater filtered through $1 \mu \mathrm{m}$ mesh in a flow-through circuit at a rate of between 12 and $15 \mathrm{l} \mathrm{h}^{-1}$, depending on the experiment. The initial number of specimens was 140 for Diets A, B and C, and 100 for Diets D, E1 and E2. Temperature was maintained at $18^{\circ} \mathrm{C}$, and salinity at $33 \%$, in all experiments. Food was supplied to the clams on a continuous basis by means of a variable-flow peristaltic pump. The seawater and food entered the tanks at mid-depth, with the outflow located at the top of the tanks.

Diets. We assayed 5 daily food rations of the microalga Isochrysyis galbana (Clone T-ISO): Diet A (0.96\%), Diet B $(0.48 \%)$, Diet C $(0.24 \%)$, Diet D $(0.05 \%)$ and Diet E $(0.025 \%)$ (percentages correspond to the organic weight of food supplied as a proportion of the live weight of the clams). The $0.025 \%$ ration was used in 2 separate experiments for clams with different amounts of initial reserves (E1 and E2).

The microalga was cultured first in 61 jars and then in $1000 \mathrm{l}$ tanks, with constant aeration and continuous light at 9000 lux. The phytoplankton used as food was harvested at the stationary growth stage.

The concentration of food entering the tanks was initially established at 120 cells $\mu^{-1}$, and in the case of Diets $A, B$ and $C$ at a flow rate of $12 \mathrm{l} \mathrm{h}^{-1}$. For Diets D and $E$, the concentration of food entering the tanks was 70 cells $\mu^{-1}$ at a flow rate of $15 \mathrm{l} \mathrm{h}^{-1}$. In order to maintain constant the daily food ration in each experiment, these parameters varied as the experiments progressed and clams were removed in successive samplings. 
In the experiments with Diets A, B and C, samples were taken at the beginning of the experiment, and then at 12, 25, 35 and $46 \mathrm{~d}$ (samples at 12 and $25 \mathrm{~d}$ were taken for histological studies only). For the experiments using Diets D and E, samples were taken at the beginning and then at 25,41 and $70 \mathrm{~d}$. On each occasion, 10 specimens were examined to determine softtissue dry weight followed by analytical examination, with a further 10 specimens used for histological studies. Where necessary, the number of specimens per sample was increased in order to obtain a minimum of 4 specimens of each sex.

Maturity indices. Soft tissue dry weight of a standard specimen: In order to calculate gonad growth, it was decided to analyse the evolution of the soft-tissue dry weight (DW) with reference to a specimen of constant size. According to the anatomical characteristics of this species, a variation in weight with no variation in size should correspond (in the main) to the accumulation or loss of reproductive tissue (Pérez Camacho 1980). To this end, the clams were dissected and their sex was determined by a smear. The soft tissues were freezedried, the weight of the freeze-dried matter being taken as the DW of the tissues. After freeze-drying, the clams were minced and an aliquot was ashed at $450^{\circ} \mathrm{C}$ for $24 \mathrm{~h}$. The remaining dry tissue was vacuum-packed for biochemical analysis at a later date.

The variation in DW was calculated on the basis of a standard clam of $22 \mathrm{~mm}$ for experiments with Diets A, $\mathrm{B}$ and $\mathrm{C}$, and a $37 \mathrm{~mm}$ clam for the experiments with Diets D and E.

Maximum oocyte diameter: Soft tissues were fixed in Bouin's fixative, dehydrated and embedded in paraffin; $4 \mu \mathrm{m}$ sections were cut (Leica DSC1) and stained in Harris' hematoxilin and eosin (Bancroft \& Stevens 1996).

MicroImage software (Olympus) was used to determine the maximum diameter of the oocytes: 9 fields of vision were used corresponding to 3 histological slices (3 different depths of the clam body), data from $>500$ oocytes were obtained for each specimen.

The oocytes were classified as young if their maximum diameter was $<25 \mu \mathrm{m}$, vitellogenic if their diameter was between $25 \mu \mathrm{m}$ and $50 \mu \mathrm{m}$, and mature if $>50 \mu \mathrm{m}$ (Delgado 2002).

Analytical methods. Protein content was calculated using the method of Lowry et al. (1951) after alkaline hydrolysis with $0.5 \mathrm{~N} \mathrm{NaOH}$ at $30^{\circ} \mathrm{C}$ for $24 \mathrm{~h}$.

Carbohydrates were determined as glucose by the phenol-sulphur method (Strickland \& Parsons 1968). Glycogen was also quantified as glucose after precipitation with $100 \%$ ethanol (Fraga 1956).

Lipids were extracted following a modification of the method of Bligh \& Dyer (1959). They were first extracted with chloroform:methanol (1:2), and after centrifugation
$(3246 \times g)$, the precipitate was again extracted with chloroform:methanol (2:1). Both supernatants were then washed with chloroform: methanol:water (8:4:3) as described by Fernández-Reiriz et al. (1989). The solvents contain $0.05 \%$ butylated hydroxytoluene (BHT). Storage until further processing was carried out under nitrogen at $-70^{\circ} \mathrm{C}$. Total lipids were gravimetrically determined after evaporation of the solvent in the purified extract on aluminium sheets at 60 to $80^{\circ} \mathrm{C}$.

Statistical methods. Statgraphics software was used to analyse the experimental results. To compare diets, samples or sexes, we used: analysis of variance (ANOVA), multifactorial ANOVA, or comparison of the slope of regression lines (minimum significance level of $\mathrm{p}<0.05)$. The preferred time interval for these comparisons was $35 \mathrm{~d}$ for Diets A, B and C, and $41 \mathrm{~d}$ for Diets D and E. Cochran's $C$-test was used to check the homogeneity of the variances. If the variances proved not to be homogeneous but there was a direct relationship between the mean and the standard deviation, then a logarithmic transformation was used. Angular transformation (arcsine $\sqrt{ } \%$ ) was applied to these parameters, expressed as percentages. A MannWhitney $U$-test and a Kruskal-Wallis test 1-way ANOVA were used when the homogeneity of the variances could not be ensured. For multiple comparisons, the differences between the treatments applied were analysed by means of the Tukey's multiple-rank test. All statistical analyses were performed according to the methods of Zar (1974) and Snedecor \& Cochran (1980).

\section{RESULTS}

\section{Maturity indices}

Variation in dry weight of standard length clam

The standard DW of a clam of $22 \mathrm{~mm}$ in length was calculated for the experiments using Diets A, B and C (Fig. 1a). The DW of the soft tissues increased over the experimental period for all 3 diets, the highest increases being registered for those diets with the largest amounts of food. The loss of weight recorded in the final sample of the clams fed on Diet A (Fig. 1a) corresponds to a partial spawning observed in the experimental tank. Occasional slight spawning was also observed in the clams fed Diet B, but this was not reflected in any variation in DW.

In the case of Diet D, the initial value for standard DW was maintained, whilst for Diet E this parameter decreased steadily over the experimental period (Fig. 1b). Histological analysis failed to correlate this weight loss with the emission of gametes. 


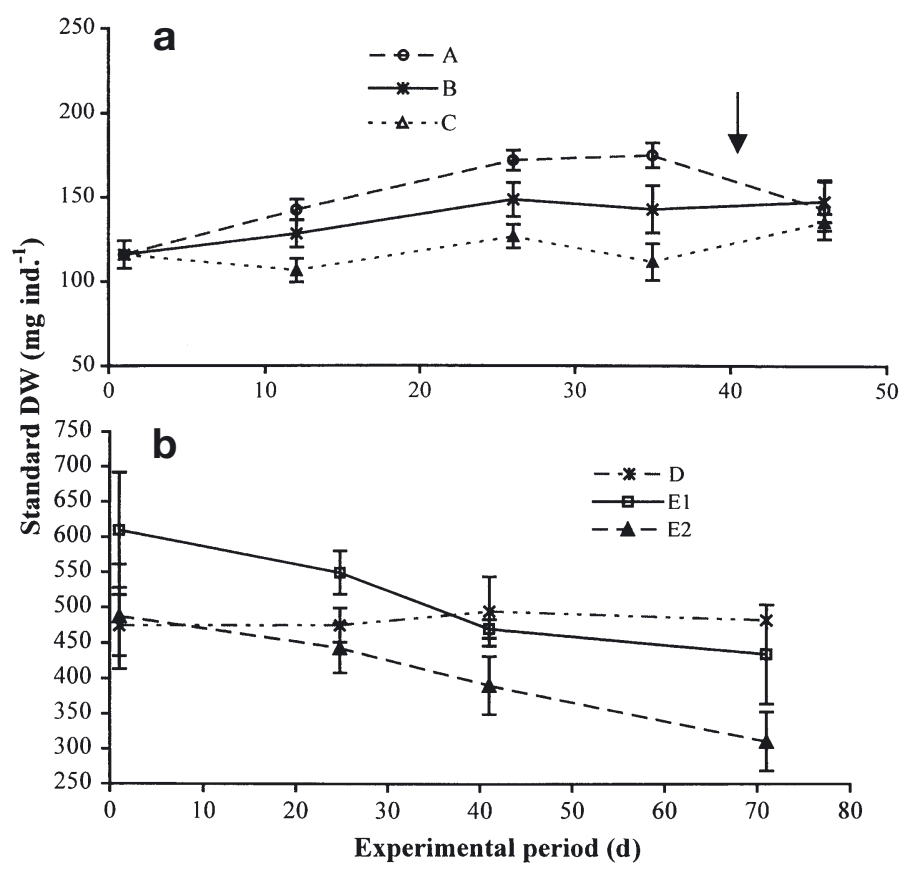

Fig. 1. Ruditapes decussatus. Mean $( \pm \mathrm{SE})$ variation in flesh dry weight (DW) of a standard clam (a) of $22 \mathrm{~mm}$ in length, fed 3 different rations of Isochrysis galbana: A $(0.96 \%), \mathrm{B}(0.48 \%)$ and C $(0.24 \%)$ (loss of weight [arrow] in final sample corresponds to partial spawning in experimental tanks); and (b) of $37 \mathrm{~mm}$ length, fed 2 different rations of I. galbana: D $(0.05 \%)$ and E $(0.025 \%)$;

(E1, E2: high and low initial level of reserves, respectively)

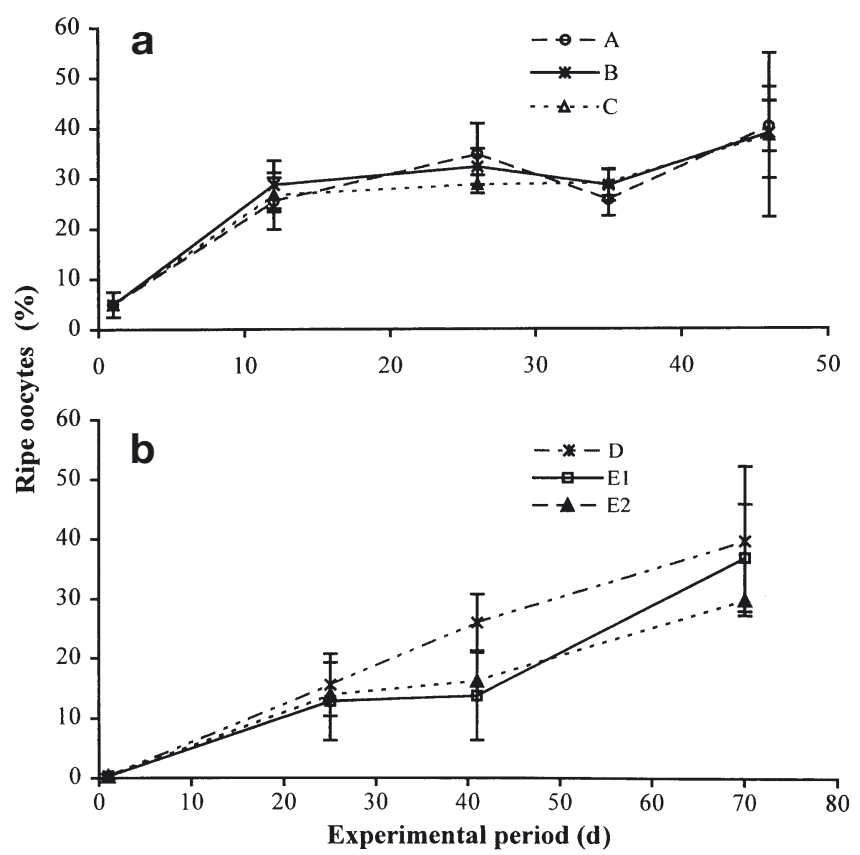

Fig. 2. Ruditapes decussatus. Mean $( \pm \mathrm{SE})$ variation in percentage of oocytes with diameter $>50 \mu \mathrm{m}$, in females (a) fed 3 different rations of Isochrysis galbana: A $(0.96 \%)$, B $(0.48 \%)$ and $\mathrm{C}(0.24 \%)$; and (b) fed 2 different rations of $I$. galbana: $\mathrm{D}(0.05 \%)$ and $\mathrm{E}(0.025 \%)$
Maximum diameter of oocytes

The clams showed a clear process of sexual maturation under all nutritive conditions over the experimental period, as reflected in an increase in the proportion of mature oocytes (i.e. those having a maximum diameter of $>50 \mu \mathrm{m}$ ) (Fig. 2).

At the highest food rations (Diets A and B), corresponding to a positive energy balance (see 'Materials and methods'), there was a rapid increase in the percentage of mature oocytes to almost $35 \%$ after $25 \mathrm{~d}$ (Fig. 2a). Thereafter, a decrease in the percentage of mature oocytes reflected the partial spawning of gametes observed in the experimental tanks and subsequent gonad recovery. The percentage of mature oocytes was at no time $>40 \%$. In the case of Diet C, which also showed a positive energy balance, the increase in percentage mature oocytes occurred at a somewhat slower rate than for Diets A and B (Fig. 2a), although the percentages for all 3 diets were similar after $46 \mathrm{~d}$. However, the linear regression lines between the proportion of mature oocytes and the natural logarithm of the number of days for the 3 diets over the first $25 \mathrm{~d}$ revealed significant differences between the slopes for Diets A and C at a confidence level of $95 \%$ (Table 1). No significant differences were observed between Diets A and B or B and C ( $p>0.05)$.

A positive variation in the percentage of oocytes with a maximum diameter of $>50 \mu \mathrm{m}$ also occurred with Diets D (zero energy balance, see 'Materials and methods') and E (negative energy balance), but at a far slower rate. These diets also achieved a maximum percentage of mature oocytes of close to $40 \%$ (Fig. 4b), although requiring $50 \%$ more time $(70 \mathrm{~d}$ as opposed to 46 d) than the diets with a positive energy balance. Sexual maturation was slower in clams fed on Diet E than in those fed on Diet D, and a comparative analysis of the slopes of the percentage-log time regression

Table 1. Ruditapes decussatus. Parameters of regression lines $(y=a+b x)$ between percentage of mature oocytes $(y)$ and the natural logarithm of number of days under experimental conditions $(x)$ in clams fed 5 different rations of Isochrysis galbana: A $(0.96 \%), \mathrm{B}(0.48 \%), \mathrm{C}(0.24 \%), \mathrm{D}(0.05 \%)$ and E $(0.025 \%)(E 1, E 2:$ high and low initial level of reserves, respectively)

\begin{tabular}{|lrcccc|}
\hline Diet & $a$ & $b$ & $\mathrm{r}^{2}$ & $\mathrm{p}$ & $\mathrm{n}$ \\
\hline $\mathrm{A}$ & 4.358 & 8.973 & 0.904 & 0.0000 & 15 \\
$\mathrm{~B}$ & 6.013 & 8.816 & 0.924 & 0.0000 & 13 \\
$\mathrm{C}$ & 6.358 & 6.811 & 0.861 & 0.0001 & 13 \\
$\mathrm{D}$ & -0.230 & 6.037 & 0.894 & 0.0000 & 13 \\
E1 & 0.351 & 3.664 & 0.896 & 0.0002 & 10 \\
E2 & -0.227 & 3.795 & 0.887 & 0.0004 & 12 \\
\hline
\end{tabular}


lines showed statistically significant differences between Diets E and D ( $p<0.05$ : Table 1).

As can be seen from Table 1, higher food rations corresponded to the steeper slopes of the percentage-time regression lines, indicating a direct relationship between the rate of gonad maturation and the available food ration.

\section{Variations in organic content (OM)}

As can be seen from Fig. 3a, for the 3 diets assayed over the first experimental period (A, B and C) there was a clearly positive energy balance, with the amount of organic matter (OM) per individual increasing in direct relationship to the available food ration. In the case of Diets A and B, there was evidence of evacuation of gametes between the second and third samples (S2 and S3), leading to a drop in OM in the final sample, and therefore comparisons between the 2 diets were based on the samples taken on Day 35. This decrease in OM was more notable in males than in females, and was greater in those clams fed on the largest ration. The differences between the maximum values recorded for each of the different food rations

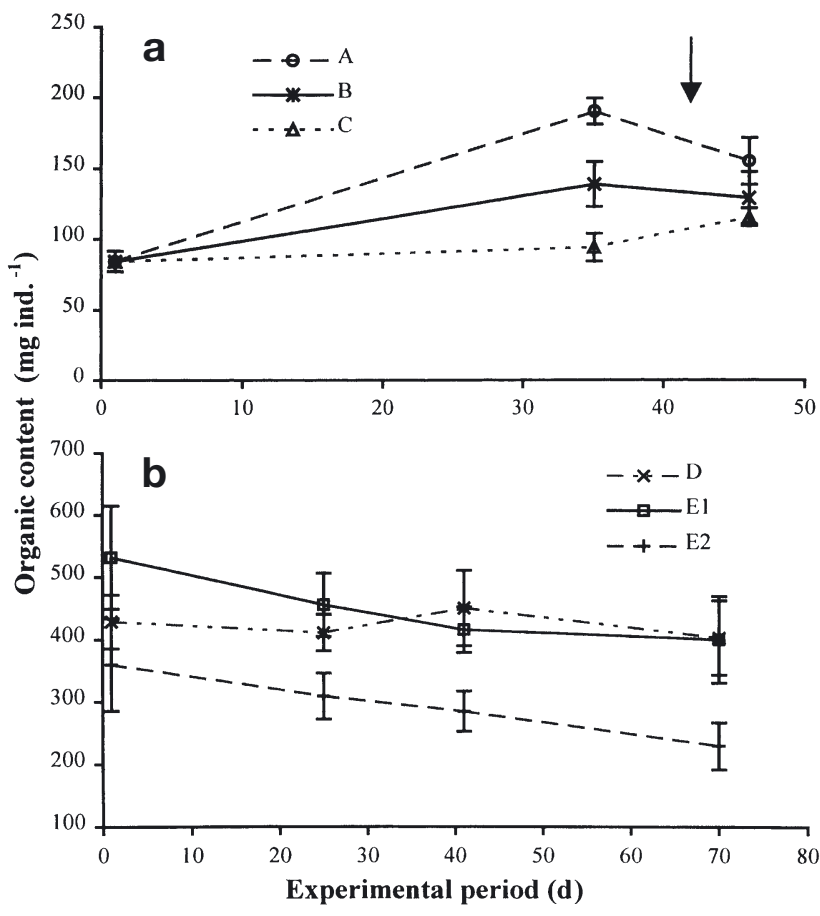

Fig. 3. Ruditapes decussatus. Mean $( \pm \mathrm{SE})$ variation in organic content of clams (a) fed 3 diets of Isochrysis galbana: A $(0.96 \%), \mathrm{B}(0.48 \%)$ and $\mathrm{C}(0.24 \%)$ during the experimental period (loss of weight [arrow] in final sample corresponds to partial spawning in experimental tanks); and (b) fed 2 diets of I. galbana: D $(0.05 \%)$ and $\mathrm{E}(0.025 \%)$ and their initial values are statistically significant (ANOVA: $\mathrm{p}<0.01$ ). The differences between food rations, based on the samples taken on Day 35, are also statistically significant (ANOVA: p < 0.001; Tukey's multiple-rank test for $95 \%$ significance level).

For the second experimental period (Fig. 3b), the amount of OM of the specimens fed on Diet D fluctuated around the initial value $(428.64 \pm 43.01)$. There was no significant difference between the different samples $(p>0.05)$, which would have indicated a zero energy balance for this diet. Finally, in the case of Diet E, which was assayed twice using clams with different levels of energy reserves, there was a clearly negative energy balance, as shown by the decrease in OM throughout the experimental period. In both assays the differences between the initial values and those of the samples taken on Day 41 (S3) were statistically significant (ANOVA: $\mathrm{p}<0.01$ for the experiment with Diet E1; Mann-Whitney $U$-test: $\mathrm{p}<0.01$ for the experiment with Diet E2).

\section{Variations in gross biochemical composition}

The results of the biochemical analyses are shown in Tables $2 \& 3$.

\section{Proteins}

For the diets showing a positive energy balance (Diets A, B and C), total protein content increased over the experimental period in direct relationship to the amount of food available (Table 2). Based on Sample 2 (S2) the analysis of variance shows statistically significant differences in total protein content $\left(\mathrm{mg}\right.$ ind. ${ }^{-1}$ ) compared with the initial content (ANOVA: $\mathrm{p}<0.001$ ) (as mentioned previously, there was evidence of gamete evacuation in the time interval between Samples S2 and S3). There were also significant differences between the 3 food rations (Sample S2) for males as well as for females (ANOVA: $\mathrm{p}<0.001$; Tukey's multiple-rank test). Expressing the biochemical composition as a percentage of OM, after $35 \mathrm{~d}$ under the experimental conditions, the percentage of proteins remained constant compared to initial levels in female clams fed the lowest food ration (Diet C), and decreased in those fed the higher rations (A and B). For the male clams, however, the protein content increased for Diet C, and decreased for Diets A and B. The differences are statistically significant between Diets A and B and Diet C for both females and males (ANOVA: $p<0.05$ and $p<0.001$, respectively; Tukey's multiple-rank test).

For the diet with zero energy balance (Diet D) gross protein content increased throughout the experimental 
period in females and males (Table 3), although at the end of this period (Sample S4) a decrease was observed that might be related to a partial spawning. The differences between protein levels in the initial samples and those of Day 41 (S3) are statistically significant (ANOVA: $p<0.01$ ) for both sexes. The percentage of proteins rose steeply at the beginning of the experimental period (S2), and then remained steady for both females and males. The differences between the initial and later samples were all statistically significant (ANOVA: $p<0.01$ ).

In conditions of negative energy balance with a relatively high initial level of reserves (Diet E1), the protein levels remained mainly constant, with only a slight, albeit not statistically significant (ANOVA between samples: $p>0.05$ ), decrease in females. In contrast to Diets $A$ to $D$, the percentage of proteins increased as the experimental period progressed, and the differences between the initial and final samples (S1 and S4, respectively) were statistically significant for both sexes (ANOVA: $\mathrm{p}<0.01$ ).

When a negative energy balance was combined with a low initial level of reserves (Diet E2), there was a statistically significant steady decrease in absolute pro- tein content in both sexes during the experimental period (ANOVA between Samples S1-S4: $\mathrm{p}<0.05$ ). As for Diet E1, the percentage proteins in Diet E2 increased over the experimental period, with the differences between Samples S1 and S4 being statistically significant for both males and females (ANOVA: $\mathrm{p}<0.001)$.

In general, the percentage protein as a function of food ration in the clams varied (as the experimental period progressed simultaneous parallel to maturation (Tables 2 \& 3). When the energy balance was positive, the protein levels remained fairly constant, but increased when the energy balance was close to zero or was negative. Likewise, the highest levels of proteins were recorded in the specimens fed the lowest diets.

\section{Carbohydrates}

In females and males (Table 2) fed diets with a positive energy balance, gross carbohydrate levels increased until Day 35 of the experimental period (S2) in proportion to the food ration administered in the case of

Table 2. Ruditapes decussatus. Biochemical composition of clams fed 3 different rations of Isochrysis galbana: A (0.96\%), B (0.48\%) and C $(0.24 \%)$. Proteins, carbohydrates, glycogen, and lipids are expressed as $\mathrm{mg}$ ind.$^{-1}$ and $\%$ organic weight $(\% \mathrm{OM})$. Means $( \pm \mathrm{SE})$ of 4 to 6 replicates. Samples taken at beginning of experimental period (S1), and after $35 \mathrm{~d}$ (S2) and $46 \mathrm{~d}$ (S3). -: data for Sample 3 in Diet A have been omitted because of gamete evacuation between S2 and S3

\begin{tabular}{|c|c|c|c|c|c|c|c|c|c|}
\hline \multirow{2}{*}{$\begin{array}{l}\text { Diet } \\
\text { Sample }\end{array}$} & \multirow{2}{*}{$\begin{array}{l}\text { Organic weight } \\
\mathrm{e} \quad \text { (mg ind. }^{-1} \text { ) }\end{array}$} & \multicolumn{2}{|c|}{ Proteins } & \multicolumn{2}{|c|}{ Carbohydrates } & \multicolumn{2}{|c|}{ Glycogen } & \multicolumn{2}{|c|}{ Lipids } \\
\hline & & (mg ind.$^{-1}$ ) & $(\% \mathrm{OM})$ & (mg ind..$^{-1}$ ) & $(\% \mathrm{OM})$ & (mg ind.$^{-1}$ ) & $(\% \mathrm{OM})$ & $\left(\mathrm{mg}\right.$ ind.$\left.^{-1}\right)$ & $(\% \mathrm{OM})$ \\
\hline \multicolumn{10}{|l|}{ Females } \\
\hline \multicolumn{10}{|l|}{ A } \\
\hline $\mathrm{S} 1$ & $84.27 \pm 7.21$ & $55.15 \pm 4.01$ & $65.44 \pm 2.02$ & $14.17 \pm 3.42$ & $16.81 \pm 2.54$ & $6.37 \pm 1.59$ & $7.56 \pm 1.58$ & $14.94 \pm 0.86$ & $17.73 \pm 0.91$ \\
\hline $\mathrm{S} 2$ & $185.57 \pm 12.86$ & $111.86 \pm 6.23$ & $60.14 \pm 1.89$ & $33.91 \pm 5.69$ & $18.27 \pm 2.01$ & $8.77 \pm 4.30$ & $4.73 \pm 2.10$ & $41.96 \pm 4.84$ & $22.61 \pm 2.12$ \\
\hline S3 & - & - & - & - & - & - & - & - & - \\
\hline \multicolumn{10}{|l|}{ B } \\
\hline $\mathrm{S} 1$ & $84.27 \pm 7.21$ & $55.15 \pm 4.01$ & $65.44 \pm 2.02$ & $14.17 \pm 3.42$ & $16.81 \pm 2.54$ & $6.37 \pm 1.59$ & $7.56 \pm 1.58$ & $14.94 \pm 0.86$ & $17.73 \pm 0.91$ \\
\hline $\mathrm{S} 2$ & $144.47 \pm 5.94$ & $87.70 \pm 6.29$ & $60.70 \pm 1.97$ & $25.93 \pm 2.50$ & $17.95 \pm 1.37$ & $7.37 \pm 1.87$ & $5.10 \pm 1.85$ & $30.83 \pm 1.58$ & $21.34 \pm 1.74$ \\
\hline S3 & $140.64 . \pm 9.54$ & $89.35 \pm 8.18$ & $63.53 \pm 1.09$ & $21.26 \pm 3.54$ & $15.11 \pm 2.02$ & $7.16 \pm 2.54$ & $5.09 \pm 1.61$ & $30.03 \pm 2.73$ & $21.35 \pm 2.08$ \\
\hline \multicolumn{10}{|l|}{$\mathrm{C}$} \\
\hline $\mathrm{S} 1$ & $84.27 \pm 7.21$ & $55.15 \pm 4.01$ & $65.44 \pm 2.02$ & $14.17 \pm 3.42$ & $16.81 \pm 2.54$ & $6.37 \pm 1.59$ & $7.56 \pm 1.58$ & $14.94 \pm 0.86$ & $17.73 \pm 0.91$ \\
\hline $\mathrm{S} 2$ & $96.72 \pm 2.36$ & $62.77 \pm 6.82$ & $64.90 \pm 1.88$ & $15.39 \pm 3.51$ & $15.91 \pm 1.64$ & $2.84 \pm 0.42$ & $2.94 \pm 0.24$ & $18.56 \pm 2.52$ & $19.19 \pm 1.25$ \\
\hline $\mathrm{S} 3$ & $117.18 \pm 8.52$ & $78.37 \pm 2.97$ & $67.31 \pm 1.76$ & $16.07 \pm 3.18$ & $13.71 \pm 2.34$ & $4.07 \pm 1.23$ & $3.47 \pm 1.11$ & $22.74 \pm 0.89$ & $19.41 \pm 0.70$ \\
\hline \multicolumn{10}{|l|}{ Males } \\
\hline \multicolumn{10}{|l|}{$\mathrm{A}$} \\
\hline $\mathrm{S} 1$ & $84.27 \pm 7.21$ & $55.15 \pm 4.01$ & $65.44 \pm 2.02$ & $14.17 \pm 3.42$ & $16.81 \pm 2.54$ & $6.37 \pm 1.59$ & $7.56 \pm 1.58$ & $14.94 \pm 0.86$ & $17.73 \pm 0.91$ \\
\hline $\mathrm{S} 2$ & $190.75 \pm 6.00$ & $122.58 \pm 17.73$ & $364.26 \pm 2.36$ & $37.45 \pm 2.91$ & $19.63 \pm 1.78$ & $9.23 \pm 1.61$ & $4.84 \pm 0.98$ & $32.74 \pm 2.34$ & $17.16 \pm 1.75$ \\
\hline S3 & $154.98 \pm 16.01$ & $103.59 \pm 11.54$ & $466.84 \pm 2.75$ & $26.92 \pm 3.75$ & $17.37 \pm 2.09$ & $8.79 \pm 1.71$ & $5.67 \pm 1.36$ & $24.47 \pm 2.95$ & $15.79 \pm 0.81$ \\
\hline \multicolumn{10}{|l|}{ B } \\
\hline $\mathrm{S} 1$ & $84.27 \pm 7.21$ & $55.15 \pm 4.01$ & $6.44 \pm 2.02$ & $14.17 \pm 3.42$ & $16.81 \pm 2.54$ & $6.37 \pm 1.59$ & $7.56 \pm 1.58$ & $14.94 \pm 0.86$ & $17.73 \pm 0.91$ \\
\hline $\mathrm{S} 2$ & $135.30 \pm 19.54$ & $89.45 \pm 13.55$ & $566.11 \pm 0.94$ & $22.28 \pm 2.59$ & $16.47 \pm 0.81$ & $6.17 \pm 1.71$ & $4.56 \pm 1.13$ & $23.57 \pm 3.66$ & $17.42 \pm 1.29$ \\
\hline $\mathrm{S} 3$ & $114.49 \pm 14.93$ & $74.22 \pm 16.27$ & $764.83 \pm 4.02$ & $18.96 \pm 3.12$ & $16.56 \pm 2.81$ & $7.39 \pm 1.41$ & $6.45 \pm 1.68$ & $21.32 \pm 1.33$ & $18.62 \pm 2.16$ \\
\hline \multicolumn{10}{|l|}{ C } \\
\hline $\mathrm{S} 1$ & $84.27 \pm 7.21$ & $55.15 \pm 4.01$ & $65.44 \pm 2.02$ & $14.17 \pm 3.42$ & $16.81 \pm 2.54$ & $6.37 \pm 1.59$ & $7.56 \pm 1.58$ & $14.94 \pm 0.86$ & $17.73 \pm 0.91$ \\
\hline $\mathrm{S} 2$ & $92.38 \pm 8.52$ & $64.88 \pm 3.94$ & $70.23 \pm 2.59$ & $12.95 \pm 2.92$ & $14.02 \pm 2.03$ & $3.05 \pm 0.67$ & $3.30 \pm 0.56$ & $14.55 \pm 2.46$ & $15.75 \pm 1.56$ \\
\hline S3 & $114.37 \pm 7.56$ & $80.14 \pm 7.05$ & $70.07 \pm 3.12$ & $15.45 \pm 1.42$ & $13.51 \pm 1.26$ & $5.60 \pm 1.95$ & $4.90 \pm 1.46$ & $18.78 \pm 3.36$ & $16.42 \pm 2.67$ \\
\hline
\end{tabular}


the 2 highest diets (A and $\mathrm{B}$ ). In the lowest of the 3 diets (C), the gross carbohydrate levels remained fairly constant (Table 2). There were statistically significant differences in the initial values for Diets A and B (ANOVA: $\mathrm{p}<0.001$ ), but not for Diet C. An analysis of variance revealed statistically significant differences between the carbohydrate content accumulated with each of the 3 diets (A, B and C) (ANOVA: p < 0.001, Tukey's multiple-rank test; females and males). The percentage of total OM represented by carbohydrates on Day 35 (S2) varied slightly from initial values (Table 2 ) in the female specimens (ANOVA: $\mathrm{p}>0.05$ ). In the male clams, the carbohydrate levels increased for clams fed Diet A, remained constant for Diet B, and decreased for Diet C. The differences between clams fed these food rations were statistically significant between Diets A and B and Diet C (ANOVA: p < 0.01; Tukey's multiple-rank test).
When the food ration administered was $<0.24 \%$, as in the diets with zero and negative energy balances (D and $\mathrm{E}$, respectively), there was a continuous decrease in carbohydrate content over the experimental period (Table 3). This decrease was most marked in the first few days of the experiment, with a more pronounced decrease at lower food rations, for which the percentage values followed much the same pattern as the absolute values, with statistically significant differences between initial and final samples in all cases (ANOVA: $\mathrm{p}<0.001$ ).

In summary, during the experimental (and sexual maturation) period, the percentage carbohydrates increased under conditions of positive energy balance ( $0.96 \%$ diet) and remained constant at the $0.48 \%$ diet. Conversely, carbohydrates decreased notably with the zero and negative energy balance diets.

Table 3. Ruditapes decussatus. Biochemical composition of clams fed 2 different rations of Isochrysis galbana: D (0.05\%) and E (0.025\%). Samples taken at beginning of experimental period (S1), and after 25 (S2), 41 (S3) and 70 d (S4); further details as in Table 2

\begin{tabular}{|c|c|c|c|c|c|c|c|c|c|}
\hline \multirow{2}{*}{$\begin{array}{l}\text { Diet } \\
\text { Samp }\end{array}$} & \multirow{2}{*}{$\begin{array}{l}\text { Organic weight } \\
\text { le }\left(\mathrm{mg} \mathrm{ind}^{-1}\right)\end{array}$} & \multicolumn{2}{|c|}{ Proteins } & \multicolumn{2}{|c|}{ Carbohydrates } & \multicolumn{2}{|c|}{ Glycogen } & \multicolumn{2}{|c|}{ Lipids } \\
\hline & & (mg ind.$^{-1}$ ) & $(\% \mathrm{OM})$ & (mg ind.$^{-1}$ ) & $(\% \mathrm{OM})$ & $\left(\mathrm{mg} \mathrm{ind}^{-1}\right)$ & $(\% \mathrm{OM})$ & (mg ind.$^{-1}$ ) & $(\% \mathrm{OM})$ \\
\hline \multicolumn{10}{|c|}{ Females } \\
\hline $\mathrm{S} 1$ & $428.64 \pm 43.01$ & $265.56 \pm 19.74$ & $62.13 \pm 2.73$ & $122.15 \pm 27.13$ & $28.25 \pm 3.97$ & $54.78 \pm 20.05$ & $12.52 \pm 3.49$ & $46.53 \pm 4.20$ & $10.92 \pm 1.24$ \\
\hline $\mathrm{S} 2$ & $398.69 \pm 24.98$ & $279.15 \pm 17.34$ & $70.05 \pm 2.16$ & $69.26 \pm 10.37$ & $17.36 \pm 2.30$ & $25.72 \pm 7.49$ & $6.43 \pm 1.72$ & $50.28 \pm 6.25$ & $12.58 \pm 1.02$ \\
\hline S3 & $450.46 \pm 49.28$ & $318.20 \pm 29.90$ & $69.76 \pm 3.06$ & $60.72 \pm 12.72$ & $14.24 \pm 2.68$ & $16.92 \pm 3.75$ & $4.01 \pm 1.00$ & $71.54 \pm 10.01$ & $15.99 \pm 0.87$ \\
\hline \multicolumn{10}{|l|}{ E1 } \\
\hline $\mathrm{S} 1$ & $531.71 \pm 82.76$ & $304.87 \pm 40.40$ & $57.59 \pm 3.05$ & $158.74 \pm 33.25$ & $29.67 \pm 2.78$ & $40.56 \pm 11.51$ & $7.53 \pm 1.70$ & $68.10 \pm 13.99$ & $12.74 \pm 1.07$ \\
\hline $\mathrm{S} 2$ & $493.45 \pm 31.36$ & $315.91 \pm 10.97$ & $64.13 \pm 2.32$ & $100.03 \pm 17.24$ & $20.16 \pm 2.44$ & $32.90 \pm 3.13$ & $6.68 \pm 0.62$ & $77.51 \pm 4.52$ & $15.71 \pm 0.26$ \\
\hline S3 & $414.44 \pm 13.51$ & $304.05 \pm 7.26$ & $73.38 \pm 0.64$ & $47.07 \pm 7.27$ & $11.34 \pm 1.39$ & $6.52 \pm 0.35$ & $1.57 \pm 0.03$ & $63.31 \pm 1.02$ & $15.29 \pm 0.74$ \\
\hline $\mathrm{S} 4$ & $392.07 \pm 72.93$ & $280.70 \pm 55.58$ & $71.50 \pm 1.83$ & $40.66 \pm 7.22$ & $10.39 \pm 0.81$ & $12.67 \pm 2.38$ & $3.25 \pm 0.45$ & $70.71 \pm 13.57$ & $18.11 \pm 2.07$ \\
\hline \multicolumn{10}{|c|}{ 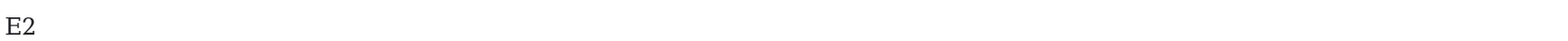 } \\
\hline $\mathrm{S} 1$ & $359.20 \pm 74.51$ & $232.53 \pm 39.71$ & $64.73 \pm 6.16$ & $84.60 \pm 31.58$ & $22.84 \pm 5.38$ & $30.96 \pm 13.08$ & $8.37 \pm 2.33$ & $42.07 \pm 9.66$ & $11.76 \pm 1.54$ \\
\hline \multicolumn{10}{|l|}{ Males } \\
\hline \multicolumn{10}{|l|}{$\mathrm{D}$} \\
\hline $\mathrm{S} 1$ & $428.64 \pm 43.01$ & $265.56 \pm 19.74$ & $62.13 \pm 2.73$ & $122.15 \pm 27.13$ & $28.25 \pm 3.97$ & $54.78 \pm 20.05$ & $12.52 \pm 3.49$ & $46.53 \pm 4.20$ & $10.92 \pm 1.24$ \\
\hline $\mathrm{S} 2$ & $437.79 \pm 19.92$ & $309.18 \pm 15.88$ & $70.61 \pm 0.83$ & $74.11 \pm 2.01$ & $16.94 \pm 2.01$ & $27.32 \pm 2.98$ & $6.23 \pm 0.47$ & $54.51 \pm 4.64$ & $12.45 \pm 0.88$ \\
\hline S3 & $447.65 \pm 92.21$ & $314.24 \pm 17.50$ & $71.79 \pm 3.26$ & $71.46 \pm 33.58$ & $15.35 \pm 2.47$ & $23.20 \pm 12.12$ & $4.96 \pm 1.70$ & $61.96 \pm 12.38$ & $13.87 \pm 0.64$ \\
\hline $\mathrm{S} 4$ & $378.27 \pm 48.75$ & $278.27 \pm 34.84$ & $73.73 \pm 1.06$ & $44.39 \pm 7.18$ & $11.71 \pm 0.79$ & $12.63 \pm 1.18$ & $3.37 \pm 0.36$ & $55.13 \pm 7.94$ & $14.56 \pm 0.64$ \\
\hline \multicolumn{10}{|l|}{ E1 } \\
\hline $\mathrm{S} 1$ & $531.71 \pm 82.76$ & $304.87 \pm 40.40$ & $57.59 \pm 3.05$ & $158.74 \pm 33.25$ & $29.67 \pm 2.78$ & $40.56 \pm 11.51$ & $7.53 \pm 1.70$ & $68.10 \pm 13.99$ & $12.74 \pm 1.07$ \\
\hline $\mathrm{S} 2$ & $412.21 \pm 65.35$ & $296.71 \pm 17.94$ & $71.38 \pm 2.96$ & $63.62 \pm 16.39$ & $15.14 \pm 3.05$ & $20.46 \pm 4.67$ & $4.90 \pm 0.98$ & $56.05 \pm 3.52$ & $13.48 \pm 0.40$ \\
\hline S3 & $415.28 \pm 41.16$ & $306.13 \pm 22.61$ & $73.94 \pm 3.81$ & $59.77 \pm 22.82$ & $12.99 \pm 2.76$ & $10.92 \pm 1.20$ & $2.64 \pm 0.29$ & $49.38 \pm 6.27$ & $11.88 \pm 0.77$ \\
\hline $\mathrm{S} 4$ & $417.09 \pm 71.38$ & $312.15 \pm 47.77$ & $75.00 \pm 1.62$ & $44.95 \pm 11.90$ & $10.66 \pm 1.06$ & $14.75 \pm 4.50$ & $3.49 \pm 0.50$ & $59.99 \pm 12.35$ & $14.34 \pm 0.81$ \\
\hline \multicolumn{10}{|l|}{$\mathrm{E} 2$} \\
\hline
\end{tabular}




\section{Glycogen}

Glycogen followed a very similar pattern to carbohydrates. As can be seen from Table 2, the absolute content of glycogen either remained constant or increased slightly at the highest diets (A and B). On the other hand, glycogen decreased in Diet C. Significant differences attributable to diet occurred in females (ANOVA: $\mathrm{p}<0.05$ ) between Diets A and B and Diet C, although there was no significant difference between the 2 latter diets (Tukey's multiple-rank test). In males, however, the differences between the 3 diets were statistically significant (ANOVA: $\mathrm{p}<0.001$; Tukey's multiple-rank test).

In the case of the remaining diets (Table 3), the amount of glycogen fell dramatically over the experimental period, particularly in the first stage of the experiment. In Diet D, the differences between the initial sample and all the other samples were statistically significant (ANOVA: $\mathrm{p}<0.001$; Tukey's multiple-rank test). The analysis of variance also shows significant differences between Sample S1 and Samples S3 and S4 in Diet E1 ( $p<0.001$; Tukey's multiple-rank test). In Diet E2, however, significant differences were found in females between the first $(\mathrm{S} 1, \mathrm{~S} 2)$ and last $(\mathrm{S} 3, \mathrm{~S} 4) 2$ samples (ANOVA: p < 0.01; Tukey's multiple-rank test). For males, significant differences were only present between S1 and S4 (ANOVA: p < 0.05; Tukey's multiple-rank test).

In relative terms for all diets, the decrease in the percentage glycogen was inversely proportional to the amount of food available. The differences between Samples S1 and S2 (Diets A, B and C) and between Samples S1 and Samples S3 and S4 (Diets D, E1 and E2) were statistically significant (ANOVA: $p<0.001$; Kruskal-Wallis test, $\mathrm{p}<0.01, \mathrm{~S} 1 \neq$ [S2 = S3]).

\section{Lipids}

The diets with a positive energy balance showed a substantial increase in lipids in both males and females as gonad maturation proceeded (Table 2). This increase was directly proportional to the amount of available food. In Diets A and B, for both sexes, there were already significant differences in clam lipid levels between the initial and the second samples (S2) (ANOVA: $\mathrm{p}<0.001$ ), but in Diet $\mathrm{C}$ the differences only became significant in the third sample (S3) (ANOVA: $p<0.001$ ). The differences between these 3 diets at the time of the second sample (S2) were also significant (ANOVA: p < 0.001; Tukey's multiple-rank test), but the amount of lipids present in females was somewhat greater than in males. These differences between the diets, however, were not statistically significant when the data were expressed as a percentage of total OM, although there was an increase over the initial value which was directly proportional to the diet (ANOVA in females, $\mathrm{p}=0.10$; in males, $\mathrm{p}=0.12$ ).

In Diet $\mathrm{D}$, with a zero energy balance, the total amount of lipids also increased throughout the experimental period, both in absolute and percentage terms, although to a much lesser extent in males than in females. Females had almost doubled their initial values by the end of the experimental period (Table 3). In both sexes the differences compared to initial values were significant in the sample taken on Day 35 (ANOVA, p < 0.01 and $p<0.001$ for males and females, respectively).

When the quantity of available food produced a negative energy balance $(0.025 \%)$ and initial reserves were relatively high (Diet E1), lipid levels remain constant in females (ANOVA between samples: $\mathrm{p}>0.05$ ). In males, however, there appeared to be a statistically significant drop in lipids compared with the initial level (ANOVA: $\mathrm{p}<0.01$, Diet $\mathrm{S} 1 \neq \mathrm{S} 3$ ).

When energy reserves were low (Diet E2), there was a decrease in lipid content in males (ANOVA: $p<0.05$; Tukey's multiple-rank test, $\mathrm{S} 1 \neq \mathrm{S} 4$ ), whilst in females the variation was not statistically significant (ANOVA: $p>0.05)$. In these diets the percentage lipids in total OM remained fairly constant (ANOVA: $p$ > 0.05), with the exception of females with high initial reserves (Diet E1), for which this percentage increased significantly during the experimental period (ANOVA: $p<0.01$; Tukey's multiple-rank test, $\mathrm{S} 1 \neq[\mathrm{S} 2=\mathrm{S} 3] \neq \mathrm{S} 4)$.

\section{Sexual differentiation}

The changes in the biochemical composition of the clams during the experimental period, which coincided with gonad maturation, clearly reflected sexual differentiation in the differences in the biochemical composition of sexually mature males and females. These differences were evident in both proteins and lipids, whereas changes in carbohydrate levels were independent of sex (Tables $2 \& 3$ ).

In sexually mature clams, the percentage of proteins was consistently higher in males than in females for diets with positive energy balances (Diets A, B and C), and the differences between the sexes were statistically significant (ANOVA: $p<0.01$, Sample S2). Under the zero (D) diet or negative energy balance diet (E1), only males in the final sample (S4) had a significantly higher proportion of proteins than females (ANOVA: $\mathrm{p}<0.01$ Diet $\mathrm{D}, \mathrm{p}<0.05$ Diet E1). When initial reserves were relatively scarce, as in the negative balance diet (E2), the difference between sexes disappeared.

The percentage lipids in total OM (Tables $2 \& 3$ ) was consistently greater in females than in males (ANOVA: $\mathrm{p}<0.01$ for Diets A, B and C; Mann-Whitney test, 
$\mathrm{p}<0.05$ for Diet $\mathrm{D}_{i}$ ANOVA: $\mathrm{p}<0.05$ for Diet E1). In this case, the amount of food available also determined the extent of these differences, since the differences lessened as the available food decreased and almost disappeared when a negative energy balance was combined with a low initial level of reserves in the organism (Diet E2).

Any variation in carbohydrate levels, including that of glycogen, occurred completely independently of the sex of the clams, with no significant differences being observed between males and females under any of the experimental conditions (ANOVA: $\mathrm{p}>0.05$ for Diets A, B, C, D and E).

\section{DISCUSSION}

Variations in the weight of OM in clams depend on the amount of available food and the amount of food ingested. Therefore, the daily rations of 9.6, 4.8 and 2.4 mg DW of phytoplankton $\mathrm{g}^{-1}$ live weight of the clams $(0.96,0.48$ and $0.24 \%)$ produced a positive energy balance, the ration of $0.5 \mathrm{mg} \mathrm{d}^{-1}(0.05 \%)$ gave a zero energy balance, and the ration of $0.25 \mathrm{mg} \mathrm{d}^{-1}(0.025 \%)$ a negative energy balance. In the experiments in the present study gonad development occurred under all these conditions, even when the energy balance was negative and the amount of $\mathrm{OM}$ in the clams decreased over the experimental period.

The amount of food available also determines, to a certain extent, whether reserves are utilised or accumulated. Thus, an abundant food supply led to an increase in all the biochemical components of the clams and had a favourable effect on gonad development. It should also be noted that this increase in total content was considerably higher for proteins and lipids.

Our results also reveal sexual differentiation in the biochemical composition of clams, associated with the process of sexual maturation, which is clearly expressed in proteins and lipids. The different biochemical composition of females and males indicates that it is essential to separate the sexes when studying changes in the biochemical composition of sexually developed specimens, and casts doubt on the results of previous studies that analysed both sexes together. In the case of female clams, taking into account the results of our histological analyses, the present study confirms the existence of a direct relationship between gonad development and lipid content. This has been observed previously in this species by Beninger \& Lucas (1984) and by Rodríguez (2000) in the clam's natural habitat.

When a positive energy balance exists, the food available is sufficient to meet the energy needs of an organism, thus leaving untouched, or even increasing, previously stored glucidic reserves. Thus, Saout et al. (1999) pointed out that if food is not a limiting factor, then Pecten maximus does not deploy energy reserves stored in the abductor muscle (glycogen in particular), whilst in winter conditions (with limited food supplies) the opposite occurs.

When no positive energy balance exists (in our study, food rations of 0.05 and $0.025 \%$ ), the amount of food ingested is insufficient to meet energy demands and an organism utilises its reserves to maintain the ongoing reproductive process and to meet the requirements of its various metabolic processes. Under these conditions there is a steady decrease in glucidic content that parallels the process of sexual maturation. This decrease affects the glycogen content (as noted by Gabbott 1975 and Rodríguez 2000), and also the gross carbohydrate content (as reported by Newell \& Bayne 1980, Navarro et al. 1989, and Álvarez 1995).

Once a large proportion of the carbohydrate reserves has been consumed, the lipids become an energy source. Some authors have suggested that lipids may form part of the reserves available to an organism in severe and prolonged situations of energy imbalance (Gabbot \& Bayne 1973, Beninger \& Lucas 1984). Our experiments partially confirm this hypothesis, and show a clear difference between the behaviour of males and females in this regard. To be more precise, (see also Table 3), males cease to accumulate lipids when the energy balance is zero (Diet D), and lipid content decreases notably when there is a negative energy balance (Diets E1 and E2). In contrast, females continue to accumulate lipids under zero energybalance conditions, and can even maintain lipids under negative energy-balance conditions when there has been a previous accumulation of reserves (Diet E1). Moreover, with a combination of negative energy balance and scarcity of reserves (Diet E2), the total lipid content in females does not notably decrease until more than 2 mo after the onset of such unfavourable conditions.

When the diet produces a zero or negative energy balance, the maintenance and loss of body weight parallels gonad maturation and an increase in oocyte size, respectively. Given the important role that lipids play in the formation of oocytes (Holland 1978), it seems clear that during gonad maturation there is a transfer of these energy reserves from other body areas to the gonad. Thus, in Chlamys opercularis, Taylor \& Venn (1979) proposed the possibility of a transfer of lipids from somatic tissue to gonad tissue, with an inverse relationship between somatic and gonad lipids.

Nevertheless, in such conditions of severe nutritive deficiency, protein levels in females only decrease to a certain extent $(22 \%)$. Despite any statistical significance, this may indicate the use of proteins as an 
energy source, a process that usually occurs during gonad maturation or during periods of serious nutritive deficiency or energy imbalance (Gabbot \& Bayne 1973, Bayne \& Newell 1983, Beninger \& Lucas 1984). More specifically, Beninger (1982) calculated that proteins supply $49 \%$ of the energy needed to maintain Ruditapes decussatus during the winter period.

Many authors agree that the use of the protein fraction as a source of energy for maintenance only takes place when carbohydrate reserves have already been greatly depleted (Barber \& Blake 1981, Larretxea 1995); this would also appear to have been the case in our experiments.

The results of the present study demonstrate the role played by lipids as a reproductive reserve in females of the species Ruditapes decussatus. Rodríguez (2000) associated the reproductive strategy of $R$. decussatus in its natural habitat in Galicia (Spain) with a conservative model, in which the accumulation of nutrients takes place prior to gametogenesis, and the conversion of glycogen reserves into lipids in the oocytes occurs during sexual maturation. Studies by González (1975) and Pérez-Camacho (1980) suggested a somewhat different model for the same geographical area. In this latter model, when spawning has taken place (normally during the latter third of summer), $R$. decussatus rapidly accumulates reserves. In the absence of gonad tissue, this process is generally based on the accumulation of glycogen (coinciding with the findings of Urrutia et al. 1999 and Rodríguez 2000). Thereafter, during autumn and winter, a series of oscillations in the organic weight of the clam occurs, leading to the total consumption of the previously accumulated reserves (coinciding with the annual minimum OM). With the arrival of spring and the subsequent increase in water temperature and phytoplankton, the organic content of this clam increases in parallel to the development of reproductive tissue, as also observed by Beninger \& Lucas (1984) for this species.

Our results allowed us to formulate a model for the utilisation of reserves during the process of sexual maturation that is closely linked to the energy balance of the clams: thus, when the energy balance is positive, the amount of food ingested provides sufficient energy for both metabolic consumption and the accumulation of reserves. Under such conditions, the process of gonad development corresponds to an increase in absolute terms of all the biochemical components, particularly lipids in females. Additionally, there is an increase in the percentage lipids in comparison with the other biochemical components, and no evidence of glycogen or carbohydrate consumption or their conversion into lipid reserves. With a zero energy balance, the total amount of lipids increases in relative terms as sexual maturation takes place, but to a much lesser extent in males than in females (females had almost doubled their initial lipid content at the end of our experiment). There is a considerable decrease in the percentage of glycogen and total carbohydrates, whilst protein levels increase slightly: in both cases the differences between the sexes are statistically significant (ANOVA: $p<0.05$ and $p<0.01$ for females and males, respectively). If the energy balance is negative, leading to a moderate weight loss in the OM of the clams (Diet E1), glycogen and other carbohydrates are rapidly consumed, falling to almost a quarter of their initial values. Protein and lipid levels, however, remain constant in females, and lipid levels in males show a slight decrease. Finally, under conditions of extreme nutritive stress (and when reserves are scarce, as in Diet E2), there is a general decrease in gross biochemical components. However, an order of priority is adhered to, with most of the glycogen and other carbohydrates (reduction of 61 and $74 \%$, respectively) being consumed, followed to a lesser extent in males by lipids (some $40 \%$ ) and then proteins (between 20 and $25 \%$ ). In females, no depletion of lipid reserves occurs until part of the proteins and most of the carbohydrates have been consumed, thus making lipids the reproductive reserve par excellence of this species.

Acknowledgements. We are grateful to P. Espiñeira, C. Pena, B. González and L. Nieto for their technical assistance. This study was financed by the project PGIDT-99MAR60401 and MAR99024002. M.D. was supported by a research personnel training grant from the European Social Fund-Spanish Oceanographic Institute (1998-1999) — and a grant from the Consello Regulador do Mexillón de Galicia (Board of Control of the Galician Mussel) (2000-2001) whilst working on this study.

\section{LITERATURE CITED}

Álvarez P (1995) Crecimiento, reproducción y energética fisiológica de la almeja Tapes philippinarum. PhD thesis, University of País, Vasco

Ansell AD (1972) Distribution, growth and seasonal changes in biochemical composition for the bivalve Donax vittatus (da Costa) from Kames Bay, Millport. J Exp Mar Biol Ecol 10:137-150

Ansell AD (1974a) Seasonal changes in biochemical composition of the bivalve Abra alba from the Clyde Sea area. Mar Biol 25:13-20

Ansell AD (1974b) Seasonal changes in biochemical composition of the bivalve Chlamys septemradiata from the Clyde Sea area. Mar Biol 25:85-99

Bancroft JD, Stevens A (1996) Theory and practice of histological techniques. Churchill Livingstone, New York

Barber BJ, Blake NJ (1981) Energy storage and utilisation in relation to gametogenesis in Argopecten irradians concentricus (Say). J Exp Mar Biol Ecol 52:121-134

Bayne BL (1976) Aspects of reproduction in bivalve molluscs. In: Wiley M (ed) Estuarine processes. 1. Uses, stresses and adaptation to the estuary. Academic Press, New York, p 432-448 
Bayne BL, Newell RC (1983) Physiological energetics of marine molluscs. In: Salenium ASM, Wilbur KM (eds) The Mollusca, Vol 4. Academic Press, New York, p 407-515

Bayne BL, Bubel A, Gabbott PA, Livingstone DR, Lowe DM, Moore MN (1982) Glycogen utilisation and gametogenesis in Mytilus edulis. Mar Biol Lett 3:89-105

Beninger PG (1982) Étude biochemique comparée de deux populations des bivalves. PhD thesis, University of Bretagne Occidentale

Beninger PG, Lucas A (1984) Seasonal variations in condition, reproductive activity, and gross biochemical composition of two species of adult clam reared in a common habitat: Tapes decussatus (L.) (Jeffreys) and Tapes philippinarum (Adams \& Reeve). J Exp Mar Biol Ecol 79:19-37

Bligh EG, Dyer WJ (1959) A rapid method of total lipid extraction and purification. Can J Biochem Physiol 37:911-917

Delgado M (2002) Maduración sexual en Ruditapes decussatus (L.). Implicaciones energéticas y bioquímicas. $\mathrm{PhD}$ thesis, University of Santiago de Compostela

de Zwaan A, Zandee DI (1972) Body distribution and seasonal changes in glycogen content of the common sea mussel Mytilus edulis. Comp Biochem Physiol A 43: 53-58

Fernández-Reiriz MJ, Pérez-Camacho A, Ferreiro MJ, Blanco J, Planas M, Campos MJ, Labarta U (1989) Biomass production and variation in the biochemical profile (total protein, carbohydrates, RNA, lipids and fatty acids) of seven species of marine microalgae. Aquaculture 83: $17-37$

Fraga F (1956) Determinación de glucógeno en moluscos con el reactivo de antrona. Investig Pesq (Barc) III: 69-74

Gabbott PA (1975) Storage cycles in marine bivalve molluscs: a hypothesis concerning the relationship between glycogen metabolism and gametogenesis. In: Barnes $\mathrm{H}$ (ed) Proc 9th Eur Mar Biol Symp, Aberdeen University Press, Aberdeen, p 191-211

Gabbott PA, Bayne BL (1973) Biochemical effects of temperature and nutritive stress on Mytilus edulis (L.). J Mar Biol Assoc UK 53:269-286

González N (1975) Composición bioquímica y medio ambiente de Venerupis decussata y Venerupis pullastra en la ría de Pasaje, La Coruña. Bol Inst Esp Oceanogr p 194

Goodman D (1979) Regulating reproductive effort in a changing environment. Am Nat 113:735-748

Holland DA (1978) Lipid reserves and energy metabolism in the larvae of bentic marine invertebrates. In: Malins DC, Sargent JR (eds) Biochemistry and biophysical perspectives in marine biology, Vol 4. Academic Press, London, p 85-123

Holland DA, Chew KK (1974) Reproductive cycle of the Manila clam (Venerupis japonica) from Hood Canal, Washington. Proc Nat Shellfish Assoc 64:53-58

Larretxea X (1995) Estudios de crecimiento en Cerastoderma edule (L.) (Bivalvia: Cardiidae): bases fisiológicas de la producción individual. $\mathrm{PhD}$ thesis, University of País, Vasco

Lowry OH, Rosebrough NH, Fair AL (1951) Protein measurements with the pholin-phenol reagent. J Biol Chem 193: $265-275$

Martínez D, Rodríguez E, Arnaíz R (1993) Ciclo reproductor de la coquina, Donax trunculus, relaciones con su contenido en proteínas, glucógeno, lípidos y ácidos grasos poliinsaturados. In: Cerviño A, Landín A, de Coo A, Guerra A, Torre M (eds) Actas IV Congreso Nacional de Acuicultura. Xunta de Galicia, Santiago de Compostela, p 347-352

Navarro JM, Iglesias JIP, Larrañaga A (1989) Interannual variation in the reproductive cycle and biochemical of the cockle Cerastoderma edule from Mundaca estuary (Biscay, North Spain). Mar Biol 101:503-511

Newell RI, Bayne BL (1980) Seasonal changes in the physiology, reproductive condition and carbohydrate content of the cockle Cardium (= Cerastoderma) edule (Bivalve: Cardiidae). Mar Biol 56:11-19

Pérez-Camacho A (1980) Biología de Venerupis pullastra (Montagu, 1803) y Venerupis decussata (Linné, 1767) (Mollusca: Bivalvia) con especial referencia a factores determinantes de la producción. Bol Inst Esp Oceanogr 281: 353-358

Robert R, Trut G, Laborde JL (1993) Growth, reproduction and gross biochemical composition of the Manila clam Ruditapes philippinarum in the Bay of Arcachon, France. Mar Biol 116:291-299

Rodríguez E (2000) Histofisiología de la reproducción de la almeja fina Ruditapes decussatus (Linné, 1758) en la Ría de Arosa (población natural y población de cultivo). $\mathrm{PhD}$ thesis, University of Santiago de Compostela

Saout C, Quéré C, Donval A, Paulet YM, Samain JF (1999) An experimental study of the combined effects of temperature and photoperiod on reproductive physiology of Pecten maximus from the Bay of Brest (France). Aquaculture 172: $301-314$

Sastry AN (1979) Pelecypoda (excluding Ostreidae). In: Giese AC, Pearse JS (eds) Reproduction of marine invertebrates, Vol 5. Academic Press, New York, p 113-292

Snedecor GW, Cochran WG (1980) Statistical methods, 7th edn. Iowa State University Press, Ames

Strickland JD, Parsons TR (1968) A practical handbook of seawater analysis. Bull Fish Res Board Can 167

Taylor AC, Venn TJ (1979) Seasonal variation in weight and biochemical composition of the tissues of the queen scallop, Chlamys opercularis, from the Clyde Sea area. J Mar Biol Assoc UK 59:605-621

Urrutia MB, Ibarrola I, Iglesias JIP, Navarro E (1999) Energetics of growth and reproduction in a high-tidal population of the clam Ruditapes decussatus from Urdaibai Estuary (Basque Country, North Spain). J Sea Res 42:35-48

Walne PR, Mann R (1975) Growth and biochemical composition in Ostrea edulis and Crassostrea gigas. In: Proc 9th Europ Mar Biol Symp, p 587-607

Zandee DI, Kluytmans JH, Zurburg W, Pieters H (1980) Seasonal variations in biochemical composition of Mytilus edulis with reference to energy metabolism and gametogenesis. Neth J Sea Res 14:1-29

Zar JH (1974) Biostatistical analysis. Prentice-Hall, Englewood Cliffs, NJ

Appendix 1. Ruditapes decussatus. Statistical analysis for \% mature oocytes

\begin{tabular}{|lccc|}
\hline Comparison & df & F-ratio & p-value \\
\hline Slopes Diets A-B & 1.25 & 0.34 & $>0.05$ \\
Slopes Diets A-C & 1.25 & 6.54 & $<0.05$ \\
Slopes Diets B-C & 1.23 & 3.72 & $=0.06$ \\
Slopes Diets D-E1 & 1.20 & 6.29 & $<0.05$ \\
Slopes Diets D-E2 & 1.22 & 7.63 & $<0.05$ \\
Slopes Diets E1-E2 & 1.19 & 0.29 & $>0.05$ \\
\hline
\end{tabular}


Appendix 2. Ruditapes decussatus. Statistical analysis for organic content (in the ANOVA, the F-ratio is the between-groups mean square value divided by the within-groups mean square value; $W$ : Mann-Whitney test statistic)

\begin{tabular}{|llrrrl|}
\hline $\begin{array}{l}\text { ANOVA } \\
\text { comparison }\end{array}$ & Sample & $\begin{array}{c}\text { df } \\
\text { (no.) }\end{array}$ & $\begin{array}{c}F \text {-ratio } \\
W \text {-value }\end{array}$ & p-value $\begin{array}{l}\text { Tukey's multiple-rank } \\
\text { test, homogeneous } \\
\text { groups }\end{array}$ \\
\hline Diet A & S1, S2 & 1.17 & 740.27 & $<0.001$ & \\
Diet B & S1, S2 & 1.16 & 91.98 & $<0.001$ & \\
Diet C & S1, S3 & 1.18 & 95.35 & $<0.001$ & \\
Diets A-B-C & S2 & 2.24 & 159.35 & $<0.001$ & $\mathrm{~A} \neq \mathrm{B} \neq \mathrm{C}$ \\
Diet D & $\mathrm{S} 1, \mathrm{~S} 2, \mathrm{~S} 3, \mathrm{~S} 4$ & 3.34 & 1.65 & $>0.05$ & $\mathrm{~S} 1=\mathrm{S} 2=\mathrm{S} 3=\mathrm{S} 4$ \\
Diet E1 & $\mathrm{S} 1, \mathrm{~S} 3$ & 1.18 & 15.14 & $<0.01$ & \\
Mann-Whitney & $\mathrm{S} 1, \mathrm{~S} 3$ & $(9.10)$ & 15.0 & $<0.01$ & \\
$U$-test, E2 & & & & & \\
\hline
\end{tabular}

Appendix 3. Ruditapes decussatus. Statistical analysis for proteins

\begin{tabular}{|c|c|c|c|c|c|}
\hline $\begin{array}{l}\text { Variable } \\
\text { ANOVA comparison }\end{array}$ & Sample & df & $F$-ratio & p-value & $\begin{array}{l}\text { Tukey test, } \\
\text { homogeneous groups }\end{array}$ \\
\hline \multicolumn{6}{|l|}{ Protein content } \\
\hline Diet A & $\mathrm{S} 1, \mathrm{~S} 2$ & 1.17 & 483.41 & $<0.001$ & \\
\hline Diet B & $\mathrm{S} 1, \mathrm{~S} 2$ & 1.16 & 83.48 & $<0.001$ & \\
\hline Diet C & $\mathrm{S} 1, \mathrm{~S} 2$ & 1.18 & 19.05 & $<0.001$ & \\
\hline Diets A-B-C (females) & $\mathrm{S} 2$ & 2.9 & 64.78 & $<0.001$ & $A \neq B \neq C$ \\
\hline Diets A-B-C (males) & $\mathrm{S} 2$ & 2.12 & 49.38 & $<0.001$ & $A \neq B \neq C$ \\
\hline Diet D (females) & $\mathrm{S} 1, \mathrm{~S} 3$ & 1.14 & 11.11 & $<0.01$ & \\
\hline Diet D (males) & $\mathrm{S} 1, \mathrm{~S} 3$ & 1.12 & 9.80 & $<0.01$ & \\
\hline Diet E1 (females) & $\mathrm{S} 1, \mathrm{~S} 4$ & 1.14 & 1.09 & $>0.05$ & \\
\hline Diet E1 (males) & $\mathrm{S} 1, \mathrm{~S} 4$ & 1.12 & 0.07 & $>0.05$ & \\
\hline Diet E2 (females) & $\mathrm{S} 1, \mathrm{~S} 4$ & 1.13 & 5.48 & $<0.05$ & \\
\hline Diet E2 (males) & $\mathrm{S} 1, \mathrm{~S} 4$ & 1.13 & 7.40 & $<0.05$ & \\
\hline \multicolumn{6}{|l|}{$\%$ Proteins } \\
\hline Diets A-B-C (females) & $\mathrm{S} 2$ & 2.9 & 7.68 & $<0.05$ & $(A=B) \neq C$ \\
\hline Diets A-B-C (males) & $\mathrm{S} 2$ & 2.12 & 19.09 & $<0.001$ & $(A=B) \neq C$ \\
\hline Diet D (females) & $\mathrm{S} 1, \mathrm{~S} 3$ & 1.14 & 27.57 & $<0.01$ & \\
\hline Diet D (males) & $\mathrm{S} 1, \mathrm{~S} 3$ & 1.12 & 17.00 & $<0.01$ & \\
\hline Diet E1 (females) & $\mathrm{S} 1, \mathrm{~S} 4$ & 1.14 & 115.07 & $<0.001$ & \\
\hline Diet E1 (males) & $\mathrm{S} 1, \mathrm{~S} 4$ & 1.12 & 86.37 & $<0.001$ & \\
\hline Diet E2 (females) & $\mathrm{S} 1, \mathrm{~S} 4$ & 1.13 & 20.44 & $<0.001$ & \\
\hline Diet E2 (males) & $\mathrm{S} 1, \mathrm{~S} 4$ & 1.13 & 23.66 & $<0.001$ & \\
\hline
\end{tabular}

Appendix 4. Ruditapes decussatus. Statistical analysis for carbohydrates

\begin{tabular}{|lclrll|}
\hline $\begin{array}{l}\text { Variable } \\
\text { ANOVA comparison }\end{array}$ & Sample & df & F-ratio & p-value & Tukey test \\
\hline Carbohydrate content & & & & & \\
Diet A & S1, S2 & 1.17 & 143.65 & $<0.001$ & \\
Diet B & S1, S2 & 1.16 & 37.40 & $<0.001$ & \\
Diet C & S1, S3 & 1.18 & 3.20 & $>0.05$ & \\
Diets A-B-C (females) & S2 & 2.9 & 18.81 & $<0.001$ & $(\mathrm{~A}=\mathrm{B}) \neq \mathrm{C}$ \\
Diets A-B-C (males) & $\mathrm{S} 2$ & 2.12 & 159.35 & $<0.001$ & $\mathrm{~A} \neq \mathrm{B} \neq \mathrm{C}$ \\
\% Carbohydrates & & & & & \\
Diets A-B-C (females) & $\mathrm{S} 2$ & 2.9 & 2.97 & $>0.05$ & $\mathrm{~A}=\mathrm{B}=\mathrm{C}$ \\
Diets A-B-C (males) & $\mathrm{S} 2$ & 2.12 & 8.62 & $<0.01$ & $(\mathrm{~A}=\mathrm{B}) \neq \mathrm{C}$ \\
Diet D (females) & $\mathrm{S} 1, \mathrm{~S} 3$ & 1.14 & 52.73 & $<0.001$ & \\
Diet D (males) & $\mathrm{S} 1, \mathrm{~S} 3$ & 1.12 & 98.47 & $<0.001$ & \\
Diet E1 (females) & $\mathrm{S} 1, \mathrm{~S} 4$ & 1.14 & 311.59 & $<0.001$ & \\
Diet E1 (males) & S1, S4 & 1.12 & 127.4 & $<0.001$ & \\
Diet E2 (females) & S1, S4 & 1.13 & 30.19 & $<0.001$ & \\
Diet E2 (males) & S1, S4 & 1.13 & 27.81 & $<0.001$ & \\
\hline
\end{tabular}


Appendix 5. Ruditapes decussatus. Statistical analysis for glycogen (in the ANOVA, the F-ratio is the between-groups mean square value divided by the within-groups mean square value; $H$ : Kruskal-Wallis test statistic)

\begin{tabular}{|c|c|c|c|c|c|}
\hline $\begin{array}{l}\text { Variable } \\
\text { ANOVA comparison }\end{array}$ & Sample & $\begin{array}{c}\mathrm{df} \\
\text { (no.) }\end{array}$ & $\begin{array}{l}F \text {-ratio } \\
H \text {-value }\end{array}$ & $\mathrm{p}$-value & $\begin{array}{l}\text { Tukey test, } \\
\text { Kruskal-Wallis test }\end{array}$ \\
\hline \multicolumn{6}{|l|}{ Glycogen content } \\
\hline Diets A-B-C (females) & $\mathrm{S} 2$ & 2.9 & 4.81 & $<0.05$ & $\mathrm{~A} \neq \mathrm{C}, \mathrm{A}=\mathrm{B}, \mathrm{B}=\mathrm{C}$ \\
\hline Diets A-B-C (males) & $\mathrm{S} 2$ & 2.12 & 27.86 & $<0.001$ & $\mathrm{~A} \neq \mathrm{B} \neq \mathrm{C}$ \\
\hline Diet D (females) & $\mathrm{S} 1, \mathrm{~S} 2, \mathrm{~S} 3, \mathrm{~S} 4$ & 3.22 & 13.13 & $<0.001$ & $\mathrm{~S} 1 \neq(\mathrm{S} 2=\mathrm{S} 3=\mathrm{S} 4)$ \\
\hline Diet D (males) & $\mathrm{S} 1, \mathrm{~S} 2, \mathrm{~S} 3, \mathrm{~S} 4$ & 3.22 & 9.44 & $<0.001$ & $\mathrm{~S} 1 \neq(\mathrm{S} 2=\mathrm{S} 3=\mathrm{S} 4)$ \\
\hline Diet E1 (females) & $\mathrm{S} 1, \mathrm{~S} 2, \mathrm{~S} 3, \mathrm{~S} 4$ & 3.21 & 18.8 & $<0.001$ & $(\mathrm{~S} 1=\mathrm{S} 2) \neq(\mathrm{S} 3=\mathrm{S} 4)$ \\
\hline Diet E1 (males) & $\mathrm{S} 1, \mathrm{~S} 2, \mathrm{~S} 3, \mathrm{~S} 4$ & 3.21 & 22.24 & $<0.001$ & $\mathrm{~S} 1 \neq(\mathrm{S} 2=\mathrm{S} 3=\mathrm{S} 4)$ \\
\hline Diet E2 (females & $\mathrm{S} 1, \mathrm{~S} 2, \mathrm{~S} 3, \mathrm{~S} 4$ & 3.24 & 6.50 & $<0.01$ & $(\mathrm{~S} 1=\mathrm{S} 2) \neq(\mathrm{S} 3=\mathrm{S} 4)$ \\
\hline Diet E2 (males) & $\mathrm{S} 1, \mathrm{~S} 2, \mathrm{~S} 3, \mathrm{~S} 4$ & 3.19 & 4.37 & $<0.05$ & $\mathrm{~S} 1 \neq \mathrm{S} 4, \mathrm{~S} 1=\mathrm{S} 2=\mathrm{S} 3, \mathrm{~S} 4=\mathrm{S} 2=\mathrm{S} 3$ \\
\hline \multicolumn{6}{|l|}{$\%$ Glycogen } \\
\hline Diets A-B-C & $\mathrm{S} 2$ & 2.26 & 5.68 & $<0.01$ & $\mathrm{~B} \neq \mathrm{C}, \mathrm{A}=\mathrm{B}, \mathrm{A}=\mathrm{C}$ \\
\hline Diets D-E1-E2 & S3 & 2.27 & 17.89 & $<0.001$ & $\mathrm{E} 1 \neq(\mathrm{D}=\mathrm{E} 2)$ \\
\hline Diet A & $\mathrm{S} 1, \mathrm{~S} 2$ & 1.17 & 30.57 & $<0.001$ & \\
\hline Diet $B$ & $\mathrm{~S} 1, \mathrm{~S} 2$ & 1.16 & 16.15 & $<0.001$ & \\
\hline Diet $C$ & $\mathrm{~S} 1, \mathrm{~S} 2$ & 1.17 & 71.59 & $<0.001$ & \\
\hline Kruskal-Wallis test, D & $\mathrm{S} 1, \mathrm{~S} 3, \mathrm{~S} 4$ & $(10,10,8)$ & 21.05 & $<0.01$ & $\mathrm{~S} 1 \neq(\mathrm{S} 3=\mathrm{S} 4)$ \\
\hline Kruskal-Wallis test, E1 & $\mathrm{S} 1, \mathrm{~S} 3, \mathrm{~S} 4$ & $(10,10,10)$ & 23.41 & $<0.001$ & $\mathrm{~S} 1 \neq(\mathrm{S} 3=\mathrm{S} 4)$ \\
\hline Kruskal-Wallis test, E2 & $\mathrm{S} 1, \mathrm{~S} 3, \mathrm{~S} 4$ & $(10,9,10)$ & 13.10 & $<0.01$ & $\mathrm{~S} 1 \neq(\mathrm{S} 3=\mathrm{S} 4)$ \\
\hline
\end{tabular}

Appendix 6. Ruditapes decussatus. Statistical analysis for lipids

\begin{tabular}{|c|c|c|c|c|c|}
\hline $\begin{array}{l}\text { Variable } \\
\text { ANOVA comparison }\end{array}$ & Sample & $\mathrm{df}$ & $F$-ratio & $\mathrm{p}$-value & Tukey test \\
\hline \multicolumn{6}{|l|}{ Lipid content } \\
\hline Diet A & $\mathrm{S} 1, \mathrm{~S} 2$ & 1.17 & 134.1 & $<0.001$ & \\
\hline Diet B & $\mathrm{S} 1, \mathrm{~S} 2$ & 1.16 & 55.73 & $<0.001$ & \\
\hline Diet C & $\mathrm{S} 1, \mathrm{~S} 3$ & 1.18 & 25.59 & $<0.001$ & \\
\hline Diets A-B-C (females) & S2 & 2.1 & 46.46 & $<0.001$ & $\mathrm{~A} \neq \mathrm{B} \neq \mathrm{C}$ \\
\hline Diets A-B-C (males) & $\mathrm{S} 2$ & 2.12 & 55.59 & $<0.001$ & $A \neq B \neq C$ \\
\hline Diet D (females) & $\mathrm{S} 1, \mathrm{~S} 3$ & 1.14 & 46.21 & $<0.001$ & \\
\hline Diet D (males) & S1, S3 & 1.12 & 12.73 & $<0.01$ & \\
\hline Diet E1 (females) & $\mathrm{S} 1, \mathrm{~S} 3$ & 1.12 & 0.92 & $>0.05$ & \\
\hline Diet E1 (males) & $\mathrm{S} 1, \mathrm{~S} 3$ & 1.14 & 12.24 & $<0.01$ & \\
\hline Diet E2 (females) & $\mathrm{S} 1, \mathrm{~S} 2, \mathrm{~S} 3, \mathrm{~S} 4$ & 3.24 & 2.11 & $>0.05$ & $\mathrm{~S} 1=\mathrm{S} 2=\mathrm{S} 3=\mathrm{S} 4$ \\
\hline Diet E2 (males) & $\mathrm{S} 1, \mathrm{~S} 2, \mathrm{~S} 3, \mathrm{~S} 4$ & 3.19 & 4.18 & $<0.01$ & $\mathrm{~S} 1 \neq \mathrm{S} 4 ;(\mathrm{S} 1=\mathrm{S} 2=\mathrm{S} 3) ;(\mathrm{S} 2=\mathrm{S} 3=\mathrm{S} 4)$ \\
\hline \multicolumn{6}{|l|}{$\%$ Lipid content } \\
\hline Diet E1 (females) & $\mathrm{S} 1, \mathrm{~S} 2, \mathrm{~S} 3, \mathrm{~S} 4$ & 3.21 & 21.88 & $<0.001$ & $\mathrm{~S} 1 \neq(\mathrm{S} 2=\mathrm{S} 3) \neq \mathrm{S} 4$ \\
\hline
\end{tabular}

Appendix 7. Ruditapes decussatus. Statistical analysis for sexual differentiation

\begin{tabular}{|lcccc|}
\hline $\begin{array}{l}\text { Variable } \\
\text { ANOVA comparison }\end{array}$ & Sample & $\begin{array}{c}\mathrm{df} \\
\text { (no.) }\end{array}$ & $\begin{array}{l}F \text {-ratio } \\
W \text {-ratio }\end{array}$ & p-value \\
\hline $\begin{array}{l}\text { \% Protein content } \\
\text { Diet A }\end{array}$ & $\mathrm{S} 2$ & 1.7 & 9.66 & $<0.05$ \\
Diet B & $\mathrm{S} 2$ & 1.6 & 28.93 & $<0.01$ \\
Diet C & $\mathrm{S} 2$ & 1.8 & 12.62 & $<0.01$ \\
Diet D & $\mathrm{S} 4$ & 1.7 & 31.70 & $<0.01$ \\
Diet E1 & $\mathrm{S} 4$ & 1.8 & 8.14 & $<0.05$ \\
Diet E2 & $\mathrm{S} 4$ & 1.8 & 1.14 & $>0.05$ \\
\% Lipid content & & & & \\
Diet A & $\mathrm{S} 2$ & 1.7 & 16.10 & $<0.01$ \\
Diet B & $\mathrm{S} 2$ & 1.6 & 20.92 & $<0.01$ \\
Diet C & $\mathrm{S} 2$ & 1.8 & 14.18 & $<0.01$ \\
Mann-Whitney $U$-test, D & $\mathrm{S} 4$ & $(4.4)$ & 0.0 & $<0.05$ \\
Diet E1 & $\mathrm{S} 4$ & 1.8 & 8.79 & $<0.05$ \\
Diet E2 & $\mathrm{S} 4$ & 1.8 & 2.87 & $>0.05$ \\
\hline
\end{tabular}

